\title{
Teaching Emotional Intelligence to Undergraduate Students
}

\author{
Sohail Amir ${ }^{1}$, Usman Mehboob ${ }^{2}$, Maimoona Qadir ${ }^{3}$, Ehsan Sethi' ${ }^{2}$, Brekhna Jamil ${ }^{2}$ \\ ${ }^{1}$ Department of Neurosurgery, Hayatabad Medical Complex, ${ }^{2}$ Department of IHPER (Institute of Health \\ Profession Education and Research), Khyber Medical University, ${ }^{3}$ Department of Obstetrics and \\ Gynecology, Khyber Teaching Hospital, Peshawar - Pakistan
}

\begin{abstract}
Emotional intelligence (EI) is how well we handle ourselves and our relationship. El may be a social intelligence that will be learned, developed, and improved. Both IQ and El are needed for success in life. But literature has proved that we need more El to be successful. Therefore, it should be taught to undergraduate students in order to increase self-confidence, improve interpersonal and communication skills, improve empathy for better patient care, buffer stress, improve problemsolving skills, developed leadership quality and all these characteristics will lead to success in life. In the literature, there are twelve different strategies; a teacher can apply to students to teach the topic effectively. Problem based learning and role-play teaching strategies will be helpful to teach the Emotional Intelligence (EI) effectively and fulfill the four competencies of El which includes selfawareness, self-motivation, empathy, and inter/intrapersonal skills development.
\end{abstract}

Keywords: Emotional Intelligence, Undergraduate Students, Competencies.

Corresponding Author: Sohail Amir

Department of Neurosurgery, Hayatabad Medical Complex, Peshawar - Pakistan

Email: dr.sohailamir@gmail.com

Date of Submission: 01-06-2021

Date of Revision: 15-06-2021

Date of Online Publishing: 30-06-2021

Date of Print: 30-06-2021

DOI: 0.36552/pjns.v25i2.562

\section{INTRODUCTION}

Emotional Intelligence (EI) is a term that refers to the manner in which we use our emotions to relieve stress, communicate effectively, commiserate with others, overcome problems, and resolve various conflicts. ${ }^{1}$ The first concept of emotional intelligence was given by Solveyr and Mayer in 1990. In the course of the last two decades, Emotional Intelligence (EI) conception has become an awfully vital indicator of a person's information, skills, and skills in geographical points, college, and personal life. The overall results of researches suggest that Emotional intelligence (EI) plays a major role within job performance, motivation, higher cognitive process, roaring management, and leadership. According to Daniel Goleman, an American psychologist who popularize emotional intelligence, state that there are four key elements 
to it. These are self-awareness; Knowing what we're experiencing and why we're feeling it is the foundation for strong intuition and making excellent decisions. The second is self-regulation, which is effectively managing your distressing emotions so that they don't get in the way of what you're doing. Emotional empathy is the third. Knowing how someone else is feeling is the fourth step, and the final step is putting everything together in a skilled relationship ${ }^{2}$. El may be a social intelligence that will be learned, developed, and improved. Both $\mathrm{IQ}$ and $\mathrm{El}$ is needed for success in life. But literature has proved that we need more El to be successful.

\section{BENEFITS OF TEACHING EI TO UNDERGRADUATE STUDENTS}

El improves a student's self-esteem. Emotional intelligence, according to Upadhyay, is a crucial aspect of generating confidence. Students with low emotional intelligence also had low levels of self-confidence, whereas students with high levels of self-confidence also had greater levels of emotional intelligence. ${ }^{3}$ El improve interpersonal and communication skill. When it comes to getting things done, effective communication with people makes all the difference. It is critical to ensure that communications are thoughtful, clear, and take into account the needs of the other party. You can handle conflicts, specific goals, influence people, and enhance listening skills by using effective, positive, well-thought-out oral and written communications. ${ }^{4}$

El is defined as the ability to understand what other people are thinking, looking at things, and imagining yourself in their shoes in an emotional context. Medical students should study emotional skills to improve their ability to notice, express, and alter their emotions in order to provide better patient care, and they should work in teams with coworkers. ${ }^{5} \mathrm{El}$ buffer stress as Education, surroundings, the curriculum in a new or modern style, domestic issue, socio-economic problems cause increased stress, fear of failure, and high anxiety levels. These things negatively affect a person's physical, social, behavioral, emotional, and cognitive development. Students who manage to deal effectively with the stress and anxiety at medical school perform well whereas those who fail to do so cannot perform up to the mark. Vaezi and Fallah narrated that the people's better dealing with stress and anxiety is attributed to their emotional intelligence. Those with high emotional intelligence (EI) can deal with stress effectively and are better adapted to their environments. ${ }^{6}$

El improve problem-solving skill, it is one of the problem-solving skills to understand how emotions can manipulate our decision-making power. This feature is related to our ability to solve a problem and it should not affect us and get affected by the people around us. If in a classroom every one of the students wants to be a winner, by the use of emotional intelligence we can handle the situation effectively and able to

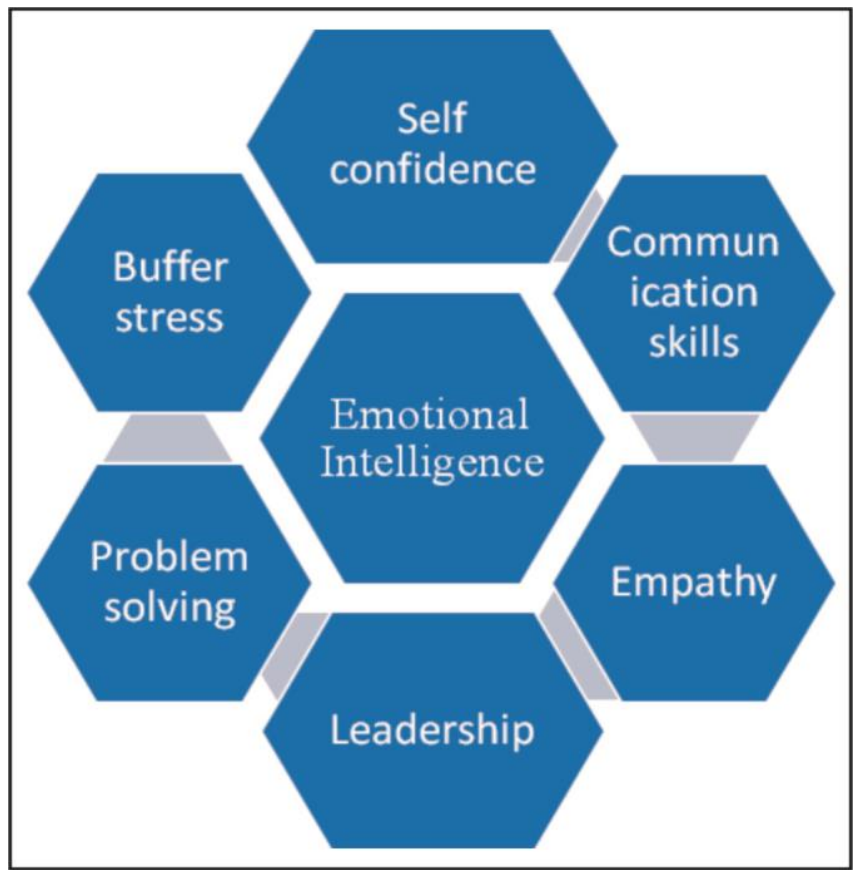

Figure 1: Benefits of teaching El to undergraduate students. develop a win-win solution. Arefnasab and Zare in 2012 studied 250 students in different universities 
of Tehran and stated that students with high $\mathrm{El}$ has better problem-solving skills than those with low El. ${ }^{7}$

El developed leadership quality in students, as It is the dream of every student to excel in his or her chosen field, and for that he needs to have high El. Students who are confident, focused, caring towards colleagues and patients, problem solving, have better communication capabilities, and can resolve disputes, will be better leaders. A study done by Aziz in June 2014 concluded that all in charges of respective departments have a high level of emotional intelligence and that male gender has more emotional intelligence than female gender. ${ }^{8-9}$

\section{TEACHING STRATEGIES}

A socially and emotionally competent teacher communicates well with students, maintains effective classroom management, and implements social and emotional learning program successfully. In the literature, there are twelve different strategies; a teacher can apply to students to teach the topic effectively. But we will discuss two teaching strategies that will be helpful to teach the El effectively and fulfill the four competencies of El.

\section{ENGAGE STUDENTS IN PROBLEM- SOLVING}

PBL (Problem-Based Learning) is a "kind of active technique, of student-centered instruction, defined by delivery of coed learning in the context of determining a real problem". ${ }^{10}$

The benefit of this strategy is that it encourages critical and creative thinking, which is necessary for identifying problems and developing acceptable solutions. Students are encouraged to monitor their comprehension and learning in order to alter their techniques, which promotes self-reflection. It also promotes students to acquire interpersonal skills like teamwork, peer review, and presentation.

A sample of 48 students was chosen and divided into two groups: control and experimental of a total population of 1281 freshmen in a study conducted by Luy-Montejo in 2019. The findings revealed that the PBL had a considerable impact on the development of emotional intelligence in the students ${ }^{11}$. Evan P's study in Katmandu in 2009 suggested that problem-based learning could be a good curricular component for increasing emotional intelligence in students.

\section{ROLE PLAY}

Skills connected to emotional learning will be tutored in exploitation scenarios drawn from student life. Literature has shown that emotional learning will come about in the brain's neural structure (limbic system) which might be learned best with observation, one on one feedback, and positive motivation. Invite students and raise them to share conflicts they need expertise in their life. Certify everybody understands the situation and establish what outcomes students wish to visualize and judge that of emotional ability the scholar uses to resolve the matter. Everybody has the task; the job of the audience is to quietly observe the actor and trust emotional ability outcomes. Rismi et al. in 2020 conducted a study which states that Group guidance services with role play techniques are considered effective in providing positive interventions to students. Role play helps individuals understand themselves in seeing a reality of community life so that they can develop skills in creative and logical thinking and can develop empathy and learning responsibly in making logical problemsolving decisions in daily life. ${ }^{12}$

\section{REFERENCES}


1. Omid A, Haghani F, Adibi P. The clinical teacher's toolkit: Clinical teaching with emotional intelligence. J Res Med Sci. 2016; 21 (2): 7-10.

2. Dev T, Vishwavidyalaya S. Emotional Intelligence: An Overview. L Lambert Acad Publ [Internet]. 2019; (August): 1-44. Available from:

https://www.researchgate.net/publication/3354334 92

3. Kant R. Emotional intelligence: A study on university students. J Educ Learn. 2019; 13 (4): 441.

4. Birks YF, Watt IS. Emotional intelligence and patient-centred care. J R Soc Med. 2007; 100 (8): 368-74.

5. Abe K, Niwa M, Fujisaki K, Suzuki Y. Associations between emotional intelligence, empathy and personality in Japanese medical students. BMC Med Educ. 2018; 18 (1): 1-9.

6. Harminder D, Gujral HK. Emotional intelligence buffers stress: a study on emotional intelligence and coping styles. Excel Int J Multidiscip Manag Stud [Internet]. 2013; 3 (11): 76-82. Available from: https://www.researchgate.net/publication/2816300 73_EMOTIONAL_INTELLIGENCE_BUFFERS_STRESS_

\section{A_STUDY_ON_EMOTIONAL_INTELLIGENCE_AND_C OPING_STYLES}

7. Arefnasab Z, Zare H, Babamahmoodi A. Emotional intelligence and problem solving strategy: $A$ comparative study basedon "tower of hanoi" test. Iran J Psychiatry Behav Sci. 2012; 6 (2): 62-8.

8. Aziz F. Emotional Intelligence as a Leadership Skill at University Level in Pakistan. J Indep Stud Res Soc Sci Econ. 2014; 12 (1): 15-30.

9. Saud WI. Emotional intelligence and its relationship to academic performance among Saudi EFL undergraduates. Int J High Educ. 2019; 8 (6): 222-30.

10. Marra $R$, Jonassen $D$, Palmer $B$, Luft $S$. Why Problem-Based Learning Works: Theoretical Foundations. J Excell Coll Teach. 2014; 25: 221-38.

11. Luy Montejo C. Problem Based Learning (PBL) in the Development of Emotional Intelligence of University Students. J Educ Psychol - Propos y Represent. 2019; 7 (2): 369-83.

12. Rismi R. The Effectiveness of Group Counseling with Role Play Techniques to Improve Student Emotional Intelligence. J ApI IPTEK Indones. 2020; 4 (2): 59-68.

\section{Additional Information}

Disclosures: Authors report no conflict of interest.

\section{Conflicts of Interest:}

In compliance with the ICMJE uniform disclosure form, all authors declare the following:

Financial Relationships: All authors have declared that they have no financial relationships at present or within the previous three years with any organizations that might have an interest in the submitted work.

Other Relationships: All authors have declared that there are no other relationships or activities that could appear to have influenced the submitted work.

\section{AUTHORS CONTRIBUTIONS AFTER REVISION}

\begin{tabular}{|l|l|l|}
\hline Sr.\# & Author's Full Name and Affiliation & Intellectual Contribution to Paper in Terms of: \\
\hline 1. & Sohail Amir & Study idea and paper writing. \\
\hline 2. & Usman Mehboob & Paper writing and Referencing. \\
\hline 3. & Maimoona Qadir & Literature review. \\
\hline 4. & Ehsan Sethi & Interpretation of results. \\
\hline 5. & Brekhna Jamil & Literature review. \\
\hline
\end{tabular}

